\title{
Neuropathic pain: new mechanisms of action of old drugs
}

\begin{abstract}
Approximately $7-10 \%$ of the general population and $30 \%$ of cancer patients suffer from neuropathic pain, which is induced by the damage or disease of the neurologic structures. Sometimes neuropathic pain is caused by the pressure on a nerve but more often pain is due to the sensitization of the centers in the spinal cord and brain. Some structures become so sensitive to the peripheral pain impulses that they become totally independent of them. Recently neuropathic pain is seen as an activation process of the innate immunologic system. In this area the Toll-like receptors seems to play an important role and many drugs are able to inhibit their activation. Treatment of neuropathic pain depends on the possibility of nerve decompression. However, in many cases, the sensitization is the target for treatment. For this purpose, most useful are gabapentinoids that inhibit influx of calcium across the membrane. Antidepressants (SNRI) such as duloxetine and venlafaxine are also useful as well as tricyclic antidepressants, although the latter are characterized by significant adverse effects. In some types of neuropathic pain $8 \%$ capsaicin, as well as $5 \%$ lidocaine plasters or different opioids, are successfully used although there is still a lack of sufficient, good quality controlled clinical trials. The description of the role of Toll-like receptors in the pathophysiology of neuropathic pain is a breakthrough in thinking and hope for the future to elaborate new, more effective treatment methods.
\end{abstract}

Palliat Med Pract 2019; 13, 3: 123-128

Key words: neuropathic pain, sensitization of the central nervous system, tricyclic antidepressants, gabapentin, pregabalin, opioids

\section{Introduction}

Chronic pain is pain that occurs frequently or continuously for several months; in the general population, one person in five suffers from chronic pain [1]. Depending on the pathomechanism, chronic pain can be divided into inflammatory pain and neuropathic pain (NP), although mixed etiology pain is often found in clinical practice. Neuropathic pain is caused by damage to or a disease of the somatosensory nervous system [2]. Based on a systematic review of studies, NP prevalence in general population was determined to be $6.9-10 \%$ [3], which means that nearly half of people who experience chronic pain suffer from NP. Based on a review of 29 studies, NP prevalence in cancer patients is $31.2 \%$ [4], but the actual figure may be higher, as mixed pain, i.e. both inflammatory and neuropathic, is frequent in this patient group [5].

Pure NP is difficult to treat, as its causes are complex and often highly varied. A single effective drug for treating all NP types is currently not available, and this is likely to remain the case in the future; however, many drugs are used for various NP types. Knowledge of the often complex pathomechanism, as well as differentiation of pain symptoms, are necessary for successful treatment of NP.

\footnotetext{
Address for correspondence:

Zbigniew Żylicz

Institute of Experimental and Clinical Medicine, University of Rzeszów, Poland

Kopisto St. 2a, Rzeszów

e-mail: z.zylicz@ur.edu.pl
}

Palliative Medicine in Practice 2019; 13, 3, 123-128

Copyright (C) Via Medica, ISSN 2545-0425

DOI: 10.5603/PMPI.2019.0016 


\section{Pathomechanism of neuropathic pain}

The term NP refers to multiple pain syndromes, whose common characteristic is damage to a nerve or the spinal cord, or, less frequently, to brain centres. This damage may be reversible, as in the case of early stages of compression neuropathies, but can also be permanent and irreversible, e.g. a nerve cut during surgery. Nerves and spinal cord can be damaged by toxic substances (e.g. chemotherapy), ionizing radiation (e.g. radiotherapy) or nerve inflammation (eg. varicella zoster virus infection). In addition, nerve damage can also occur due to changes in metabolism (e.g. caused by diabetes) and many other factors, not all of which are understood at present. Studying the pathomechanism of NP is difficult, as animal models (e.g. sciatic nerve clamping in rats) do not fully reflect human pathology [6], and furthermore, animals most likely do not experience emotional distress as a result of the procedure. Other animal models of nerve damage are also available, but the difficulty lies in translating experimental data into pathomechanism and humans' perception of NP.

The process which leads to NP can be divided into three phases. The first phase is damage, the second phase is an attempt to regenerate the nerve [6], the third phase involves secondary changes in the CNS, in general termed central sensitization [7]. Damage to a nerve or other nervous structure leads to development of necrosis and atrophy of both distal and proximal sections of damaged axons. A trophic response occurs in the spinal cord and brain centers, which involves increased gene expression and synthesis of nerve growth factors (neurotrophins), including the nerve growth factor (NGF) [7]. Neurotrophins and their precursors are responsible for regeneration of axons, which, if possible, grow into existing nerve sheaths. At the same time, neurotrophins, including NFG, activate macrophages and microglia cells and constitute the part of the neurogenic inflammation process [8] which is responsible for sustaining, i.e. chronification, of pain [9].

Most often there is effective nerve regeneration, and the symptoms of hypoalgesia and numbness disappear after a few months, depending on the length of the axon. Regeneration of the longest foot nerves can take significantly longer compared to a cutaneous nerve on the torso cut by a surgeon, e.g. during a surgery of the abdominal cavity. If the nerve regeneration is complete, the neurogenic inflammation process gradually subsides. In some cases, the regeneration process may be incomplete or disturbed, e.g. in diabetes [6], which leads to chronification of pain and persistence of the neurogenic inflammation.
Moreover, this process can expand and intensify. If the axons are unable to grow into existing nerve sheaths or if they encounter obstacles on their path, such as a scar or an amputated end of a nerve, they grow chaotically as a small tumour - a neuroma - which is very sensitive to mechanical damage and can cause increased pain $[10,11]$.

In recent years, the role of Toll-like receptors [12] located on the surface of microglia in the spinal cord has been pointed out. 10 different types of these receptors have been found in humans, but only some (notably TLR-2 and TLR-4) are related to chronification of pain, including NP [13-15]. These receptors constitute a very important element of the innate immunity system, and in the human body they quickly react to changes in the internal and external environment. Following an infection with e.g. typhus bacteria, signals from the intestinal flora are sent to the CNS via lipopolysaccharides (LPS) of bacterial origin, which bind to receptors and cause a cascade of reactions involving production of inflammatory cytokines [16], which are responsible for neutralizing and removing the bacteria from the body (neurogenic inflammation). Under certain circumstances, e.g. microbiome disorders in the large intestine, there is a constant stimulation of Toll-like receptors. [17] Years later, such processes are responsible for almost all neurodegenerative diseases [18-20], mental depression [21] and development of opioid-induced tolerance and hyperalgesia [22].

Toll-like receptors are also interesting because they react with various drugs. Morphine-3-glucuronide, a morphine metabolite, reacts with TLR-4 and causes an increase in proinflammatory cytokine production, which in turn leads to a pronociceptive effect (weakening of analgesia) [23, 24]. The above may explain the development of opioid-induced hyperalgesia, here caused by administration of morphine. Tolllike receptors also react with other opioids, such as fentanyl [25], which explains the short-lasting effect of the drug in treatment of NP [26] and its reduced effectiveness over time due to activation of neurogenic inflammation and anti-analgesic effect [27]. Toll-like receptors also react with naloxone (both dextro-naloxone and levo-naloxone), which leads to inhibition of development of neurogenic inflammation [28]. This is significant because inactive (+)-naloxone, as an opioid antagonist, proved effective in treating NP in animals [15]. Tricyclic antidepressants inhibit the activation of Toll-like receptors [29], which may explain their analgesic effect in NP.

Another receptor which plays an important role in development of sensitization and hyperalgesia is the NMDA (N-methyl-D-aspartate) glutamate receptor [30]. This receptor, or rather the ion channel, reacts 
to binding with glutamic acid by releasing a magnesium ion, which blocks the channel. Magnesium deficiency causes "opening", i.e. activation, of the ion channel, while magnesium sulfate administered via the parenteral route is an effective, though not as effective as ketamine, inhibitor of the NMDA receptor [31]. The effects of ketamine administration are likely also related to interaction with Toll-like receptors [32].

Inhibition of CNS sensitization causes inhibition of calcium channels after administration of gabapentin and pregabalin (gabapentinoids), which reduce the sensitivity of the posterior horns of the spinal cord through several mechanisms [33]. Drugs from this group inhibit calcium transport, block the release of pronociceptive neurotransmitters by inhibiting the $\alpha 2 \delta-1$ subunit and activate glutamate uptake by excitatory amino acid transporter proteins [34]. Other mechanisms of action of gabapentinoids include the impact on the emotional sphere, which is significant in terms of pain sensation; for this reason, pregabalin is increasingly used in psychiatry [35]. In palliative care, gabapentinoids are also used to treat such symptoms as coughing, restless legs syndrome, itching and hiccups, which are caused by CNS sensitization [36].

\section{Diagnosis of neuropathic pain}

Clinical diagnosis of NP is based on medical history and physical examination. A patient suffering from NP may experience spontaneous stabbing, piercing pains, "as if after an electrical impulse", as well as numbness, cracking, tearing and burning. The patient may use different words and describe the pain differently than above. Many questionnaires can be helpful in diagnosing NP [37], but they take a lot of time and so they are used more often in scientific research than in clinical practice, where, especially in the context of long-term pain management, pain intensity scales are more useful [15].

In physical examination, testing the superficial sensation of the skin plays the most important role; disorders of that sensation are referred to as dysaesthesias. Sensation may be impaired (hypoesthesia), or the patient may be hypersensitive, not only to naturally painful impulses (hyperalgesia), but also to being touched with a cotton pad or a fingertip (allodynia). The test is performed using special, blunt needles or a bent paper clip, as well as a cotton pad. It is important to determine whether the observed changes concern an area supplied by a single nerve or a nerve root (dermatome). In the first case, hyperalgesia (blunt needle test) in a single nerve area suggests peripheral nerve involvement or compression. An area of hyperalgesia coinciding with a dermatome suggests damage at the spinal cord segment and nerve root level. In such a case, performing an imaging examination, e.g. MRI of the spinal cord, is recommended. Pain caused by a compressed nerve can be provoked by pressing on or palpation of the nerve area, which sometimes causes radiating pain along the compressed nerve. The attending physician should also prepare a detailed description of the pain phenomenon, including assessment of pain intensity using the numeric rating scale (NRS) [15] for both pain experienced spontaneously as well as pain experienced after stimulation; this plays an important role in subsequent assessment of effectiveness of treatment.

\section{Treatment of neuropathic pain}

Non-sustained neuropathies caused by a compressed nerve are the easiest to treat. It is very important to decompress the nerve by performing surgery. Drug therapy often involves the use of corticosteroids (of which dexamethasone is the most frequently administered, either via the oral route or the parenteral route), which have anti-inflammatory and anti-edematous effects, useful also in treatment of elevated intracranial pressure and compressed spinal cord. When a tumour presses on a nerve structure (e.g. nerve plexus), corticosteroids can be used in conjunction with radiotherapy or chemotherapy. Intense pain caused by a single nerve pressing against a bone edge or a tendon or by entrapment of a nerve in a very tense muscle occurs frequently in palliative care practice; in such a case, it is best to apply topical injections of a mixture of methylprednisolone and bupivacaine around the nerve [38].

Unfortunately, most NP patients consult a doctor too late, when irreversible changes have already occured; at this stage, the goal of treatment is to reduce CNS sensitization. Up until now, it was believed that drugs affecting reuptake of monoamines as well as sodium channel blockers are effective in NP treatment. Currently, however, it is unclear whether the aforementioned mechanisms really are the most important, as it transpired that tricyclic antidepressants can act via Toll-like receptors, while antidepressants which inhibit serotonin reuptake (SSRIs) are ineffective in NP treatment.

The effectiveness of tricyclic antidepressants (TCAs) has been sufficiently determined [39]. The mechanism of action of this group drugs is not thoroughly understood, but they cause a number of side effects, which can be very troublesome in patients with an advanced disease and in the elderly. Adverse effects are caused mainly by the cholinolytic effect, which is not necessary to achieve an analgesic effect. The 
number of patients who have to be treated in order to achieve at least a $50 \%$ reduction in pain intensity (number needed to treat, NNT) is 3.6 (3.0-4.4) [39]. Amitriptyline is the best-known drug, but it also causes multiple side effects. In this respect, imipramine and nortriptyline are much better tolerated; unfortunately, the availability of these drugs in Poland is low. TCAs should be administered typically once per day at bedtime, starting from low doses, and treatment should not be suddenly stopped. As already mentioned, TCAs inhibit the activity of Toll-like receptors, and it is possible that this mechanism is responsible for the analgesic effects in NP. Because Toll-like receptors are not stereospecific, dextrorotatory drug enantiomers may have inhibitory effects on Toll-like receptors; at the same time, they have a different profile of adverse effects [28]. At present, the role of the mechanism of inhibition of neurogenic inflammation in effectiveness of this group of drugs is unknown.

Newer antidepressants whose mechanism of action is similar to TCAs include duloxetine and venlafaxine (SNRIs). These drugs cause substantially fewer side effects compared to TCAs. NNT for this group of drugs is 6.4 (5.2-8.4). Side effects include nausea, vomiting and constipation, as well as increased blood pressure. In patients with liver failure and heart failure, drugs should be administered at lower doses, and should not be combined with tramadol due to risk of serotonin syndrome [40].

Currently, the most commonly used drugs are gabapentinoids: gabapentin and pregabalin, which inhibit calcium channels and lead to reduction of CNS sensitization. These drugs are usually well tolerated and their adverse effects are usually mild. Although NNT for gabapentin is 6.3 (5.0-8.4), while for pregabalin NNT is 7.7 (6.5-9.4) [39], these drugs are considered to be among the most effective in NP treatment.

Patches containing $5 \%$ lidocaine, which inhibits sodium channels, are used topically if pain is limited to a small area of the skin. NNT has not yet been established [39], but side effects are very limited and the drug is not contraindicated for patients with heart diseases. Unfortunately, antiarrhythmic agents administered orally proved to be ineffective and burdened with serious adverse effects. Another topical treatment is $8 \%$ capsaicin used in patches, which inhibits type 1 vanilloid receptors (TRPV1) in the skin. NNT is 10.6 (7.4-19) [39], but so far too few controlled clinical trials have been carried out to conclusively determine the effectiveness of treatment [39]. The drug is very expensive and fairly difficult to use. Safe treatment is possible in specialist pain clinics, whose staff includes doctors and nurses trained in this area. Capsaicin administered at this concentration can cause blindness in contact with the cornea of the eye [41].

Botulinum toxin type $A$ is another topically acting drug with high efficacy - NNT 1.9 (1.5-2.4) [39]. After injection into the painful area, it inhibits acetylcholine surge and reduces the activity of striated muscles. This drug is very useful in treating nerves entrapped in very tense muscles, e.g. in compression neuropathy of the occipital nerve, which causes intense, paroxysmal headaches [38].

The use of opioids in NP treatment is quite controversial, especially with respect to non-cancer pain [42]. On one hand, although NNT for opioids is fairly low, at 4.3 (3.4-5.8) [39], more side effects and relatively fast development of tolerance are observed during treatment compared to treatment of other types of pain [42].The best results are obtained in treatment of mixed inflammatory and neuropathic pain [43]. On the other hand, it is traditionally believed that certain opioids have specific properties which are beneficial in NP treatment. For example, methadone has an additional analgesic effect caused by inhibition of the NMDA receptor by the dextrorotatory D-methadone isomer [44], though increased effectiveness of methadone in NP treatment has not been confirmed in controlled clinical trials [45].

Another opioid which has "special" properties in NP treatment is buprenorphine, most commonly used in patches [46], which shows effects similar to local anesthetics, i.e. blocking of sodium channels [47]; however, there is no clinical evidence for such effects of the drug. Ten controlled studies failed to demonstrate a more effective analgesic effect of buprenorphine in NP [48]. Buprenorphine is most commonly used in conjunction with gabapentin or pregabalin, and can be administered to patients with kidney failure. Another opioid with "special" properties in NP is tramadol [49], a "weak" opioid with a complex mechanism of analgesic action. NNT for tramadol is 4.7 (3.6-6.7) [39], whereas for other, "stronger" opioids, it is lower; however, evidence for effectiveness of tramadol in NP treatment is limited [49].

Traditionally, other drugs, which in light of obtained clinical evidence have received only limited recommendations, have been used in NP treatment [39]. Unfortunately, tapentadol has failed to prove a breakthrough so far; despite promising results of some studies [50], too little independent clinical data confirming effectiveness of tapentadol in NP treatment is available. Anticonvulsants other than gabapentinoids are not widely used in treatment of neuropathic pain. Due to numerous side effects and interactions with other drugs, carbamazepine is used only to treat trigeminal neuralgia [51]. Oxcarbazepine, 
a carbamazepine derivative, is a less toxic drug, but evidence of its effectiveness is also limited [52]. Ketamine, an inhibitor of NMDA receptors, which has traditionally been used to manage pain, including $\mathrm{NP}$, in cancer patients, proved ineffective in controlled studies which compared the drug, administered orally, with a placebo [53].

\section{Summary}

Sustained NP is difficult to treat, and its pathomechanism is highly varied and still poorly understood. In many cases of severe NP, it is advisable to combine several drugs. The "trial and error" method, wherein a single patient's drugs are changed multiple times, is common in NP treatment; this negatively affects the patient's mental state as well as trust in attending physicians. Many patients use other drugs on their own, which can be potentially harmful.

Based on improving understanding of pathomechanism of NP, new, more effective drugs can be expected in the near future. Increasing importance of Toll-like receptors in pathomechanism of NP has other aspects as well. It is possible that drugs which have proven effective in treating NP, such as amitriptyline, work in a completely different way than hitherto believed. Because Toll-like receptors are not stereoselective, and most drugs administered to patients are mixtures of enantiomers (racemates), it is worth considering whether those enantiomers which have always been believed to be inactive are not responsible for pharmacological effects [14, 15], at least in test animals, which would open completely new possibilities for researching new drugs.

\section{References}

1. Breivik H, Collett B, Ventafridda V, et al. Survey of chronic pain in Europe: prevalence, impact on daily life, and treatment. Eur J Pain. 2006; 10(4): 287-333, doi: 10.1016/j. ejpain.2005.06.009, indexed in Pubmed: 16095934.

2. Jensen $T$, Baron $R$, Haanpää $M$, et al. A new definition of neuropathic pain. Pain. 2011; 152(10): 2204-2205, doi: 10.1016/j.pain.2011.06.017.

3. van Hecke O, Austin SK, Khan RA, et al. Neuropathic pain in the general population: a systematic review of epidemiological studies. Pain. 2014; 155(4): 654-662, doi: 10.1016/j. pain.2013.11.013, indexed in Pubmed: 24291734.

4. Roberto A, Deandrea S, Greco MT, et al. Prevalence of Neuropathic Pain in Cancer Patients: Pooled Estimates From a Systematic Review of Published Literature and Results From a Survey Conducted in 50 Italian Palliative Care Centers. J Pain Symptom Manage. 2016; 51(6): 1091-1102. e4, doi: 10.1016/j.jpainsymman.2015.12.336, indexed in Pubmed: 27017920.

5. Fallon MT. Neuropathic pain in cancer. Br J Anaesth. 2013; 111(1): 105-111, doi: 10.1093/bja/aet208, indexed in Pubmed: 23794652.

6. Scheib J, Höke A. Advances in peripheral nerve regeneration. Nat Rev Neurol. 2013; 9(12): 668-676, doi: 10.1038/nrneurol.2013.227, indexed in Pubmed: 24217518.
7. Latremoliere A, Woolf CJ. Central sensitization: a generator of pain hypersensitivity by central neural plasticity. J Pain. 2009; 10(9): 895-926, doi: 10.1016/j.jpain.2009.06.012, indexed in Pubmed: 19712899.

8. Williams KS, Killebrew DA, Clary GP, et al. Differential regulation of macrophage phenotype by mature and pro-nerve growth factor. J Neuroimmunol. 2015; 285: 76-93, doi: 10.1016/j.jneuroim.2015.05.016, indexed in Pubmed: 26198923.

9. DeLeo JA, Yezierski RP. The role of neuroinflammation and neuroimmune activation in persistent pain. Pain. 2001; 90(1-2): 1-6, doi: 10.1016/s0304-3959(00)00490-5, indexed in Pubmed: 11166964.

10. Singson RD, Feldman F, Slipman CW, et al. Postamputation neuromas and other symptomatic stump abnormalities: detection with CT. Radiology. 1987; 162(3): 743-745, doi: 10.1148/radiology.162.3.3809488, indexed in Pubmed: 3809488.

11. Salemis NS. Traumatic neuroma as a rare cause of intractable neuropathic breast pain following cancer surgery: Management and review of the literature. Intractable Rare Dis Res. 2018; 7(3): 185-190, doi: 10.5582/irdr.2018.01041, indexed in Pubmed: 30181939.

12. De Nardo D. Toll-like receptors: Activation, signalling and transcriptional modulation. Cytokine. 2015; 74(2): 181-189, doi: 10.1016/j.cyto.2015.02.025, indexed in Pubmed: 25846205.

13. Jurga AM, Rojewska E, Piotrowska A, et al. Blockade of Toll-Like Receptors (TLR2, TLR4) Attenuates Pain and Potentiates Buprenorphine Analgesia in a Rat Neuropathic Pain Model. Neural Plast. 2016; 2016: 5238730, doi: 10.1155/2016/5238730, indexed in Pubmed: 26962463.

14. Lewis SS, Loram LC, Hutchinson MR, et al. (+)-naloxone, an opioid-inactive toll-like receptor 4 signaling inhibitor, reverses multiple models of chronic neuropathic pain in rats. J Pain. 2012; 13(5): 498-506, doi: 10.1016/j.jpain.2012.02.005, indexed in Pubmed: 22520687.

15. Hutchinson MR, Zhang $Y$, Brown $K$, et al. Non-stereoselective reversal of neuropathic pain by naloxone and naltrexone: involvement of toll-like receptor 4 (TLR4). Eur J Neurosci. 2008; 28(1): 20-29, doi: 10.1111/j. 1460-9568.2008.06321.x, indexed in Pubmed: 18662331.

16. Harrison NA, Brydon $L$, Walker $C$, et al. Inflammation causes mood changes through alterations in subgenual cingulate activity and mesolimbic connectivity. Biol Psychiatry. 2009; 66(5): 407-414, doi: 10.1016/j.biopsych.2009.03.015, indexed in Pubmed: 19423079.

17. Moresco EM, LaVine D, Beutler B. Toll-like receptors. Curr Biol. 2011; 21(13): R488-R493, doi: 10.1016/j. cub.2011.05.039, indexed in Pubmed: 21741580.

18. Velasquez-Manoff M. Gut microbiome: the peacekeepers. Nature. 2015; 518(7540): S3-11, doi: 10.1038/518S3a, indexed in Pubmed: 25715278.

19. Doorn KJ, Moors T, Drukarch B, et al. Microglial phenotypes and toll-like receptor 2 in the substantia nigra and hippocampus of incidental Lewy body disease cases and Parkinson's disease patients. Acta Neuropathol Commun. 2014; 2: 90, doi: 10.1186/s40478-014-0090-1, indexed in Pubmed: 25099483.

20. Fitzpatrick JMK, Downer EJ. Toll-like receptor signalling as a cannabinoid target in Multiple Sclerosis. Neuropharmacology. 2017; 113(Pt B): 618-626, doi: 10.1016/j. neuropharm.2016.04.009, indexed in Pubmed: 27079840.

21. Rich T, Zhao F, Cruciani RA, et al. Association of fatigue and depression with circulating levels of proinflammatory cytokines and epidermal growth factor receptor ligands: a correlative study of a placebo-controlled fatigue trial. Cancer Manag Res. 2017; 9: 1-10, doi: 10.2147/CMAR. S115835, indexed in Pubmed: 28203105. 
22. Grace P, Maier S, Watkins L. Opioid-Induced Central Immune Signaling: Implications for Opioid Analgesia. Headache: The Journal of Head and Face Pain. 2015; 55(4): 475-489, doi: 10.1111/head.12552.

23. Due MR, Piekarz AD, Wilson N, et al. Neuroexcitatory effects of morphine-3-glucuronide are dependent on Toll-like receptor 4 signaling. J Neuroinflammation. 2012; 9: 200, doi: 10.1186/1742-2094-9-200, indexed in Pubmed: 22898544.

24. Lewis SS, Hutchinson MR, Rezvani N, et al. Evidence that intrathecal morphine-3-glucuronide may cause pain enhancement via toll-like receptor 4/MD-2 and interleukin-1 beta. Neuroscience. 2010; 165(2): 569-583, doi: 10.1016/j. neuroscience.2009.10.011, indexed in Pubmed: 19833175.

25. Hutchinson MR, Zhang $Y$, Shridhar $M$, et al. Evidence that opioids may have toll-like receptor 4 and MD-2 effects. Brain Behav Immun. 2010; 24(1): 83-95, doi: 10.1016/j. bbi.2009.08.004, indexed in Pubmed: 19679181.

26. Dellemijn PL, Vanneste JA. Randomised double-blind active-placebo-controlled crossover trial of intravenous fentanyl in neuropathic pain. Lancet. 1997; 349(9054): 753-758, doi: 10.1016/\$0140-6736(96)09024-1, indexed in Pubmed: 9074573.

27. Bleeker CP, Bremer RC, Dongelmans DA, et al. Inefficacy of high-dose transdermal fentanyl in a patient with neuropathic pain, a case report. Eur J Pain. 2001; 5(3): 325-9; discussion 329, doi: 10.1053/eujp.2000.0220, indexed in Pubmed: 11558988.

28. Wang $X$, Zhang $Y$, Peng $Y$, et al. Pharmacological characterization of the opioid inactive isomers $(+)$-naltrexone and (+)-naloxone as antagonists of toll-like receptor 4. Br J Pharmacol. 2016; 173(5): 856-869, doi: 10.1111/bph.13394, indexed in Pubmed: 26603732.

29. Hutchinson MR, Loram LC, Zhang Y, et al. Evidence that tricyclic small molecules may possess toll-like receptor and myeloid differentiation protein 2 activity. Neuroscience. 2010; 168(2): 551-563, doi: 10.1016/j.neuroscience.2010.03.067, indexed in Pubmed: 20381591.

30. Suarez-Roca H, Silva JA, Arcaya JL, et al. Role of mu-opioid and NMDA receptors in the development and maintenance of repeated swim stress-induced thermal hyperalgesia. Behav Brain Res. 2006; 167(2): 205-211, doi: 10.1016/j. bbr.2005.09.006, indexed in Pubmed: 16214233.

31. Felsby S, Nielsen J, Arendt-Nielsen L, et al. NMDA receptor blockade in chronic neuropathic pain: a comparison of ketamine and magnesium chloride. Pain. 1996; 64(2): 283-291, doi: 10.1016/0304-3959(95)00113-1, indexed in Pubmed: 8740606.

32. Mei XP, Zhou Y, Wang W, et al. Ketamine depresses toll-like receptor 3 signaling in spinal microglia in a rat model of neuropathic pain. Neurosignals. 2011; 19(1): 44-53, doi: 10.1159/000324293, indexed in Pubmed: 21389680.

33. Chincholkar M. Analgesic mechanisms of gabapentinoids and effects in experimental pain models: a narrative review. Br J Anaesth. 2018; 120(6): 1315-1334, doi: 10.1016/j. bja.2018.02.066, indexed in Pubmed: 29793598.

34. Sills GJ. The mechanisms of action of gabapentin and pregabalin. Curr Opin Pharmacol. 2006; 6(1): 108-113, doi: 10.1016/j.coph.2005.11.003, indexed in Pubmed: 16376147.

35. Berlin RK, Butler PM, Perloff MD. Gabapentin Therapy in Psychiatric Disorders: A Systematic Review. Prim Care Companion CNS Disord. 2015; 17(5), doi: 10.4088/PCC.15r01821, indexed in Pubmed: 26835178.

36. Zylicz Z. Krajnik, M., : The effect of gabapentin and pregabalin on symptoms other than pain and seizures. A review of the evidence. Adv Pall Med. 2008; 4: 179-184.

37. Loblaw DA, Perry J, Chambers A, et al. Systematic review of the diagnosis and management of malignant extra- dural spinal cord compression: the Cancer Care Ontario Practice Guidelines Initiative's Neuro-Oncology Disease Site Group. J Clin Oncol. 2005; 23(9): 2028-2037, doi: 10.1200/JCO.2005.00.067, indexed in Pubmed: 15774794.

38. Żylicz Z. Diagnosis and treatment of nerve entrapment neuropathiesin Palliative Medicine. Ból. 2018; 19(1): 37-41, doi: 10.5604/01.3001.0012.5930.

39. Attal N. Pharmacological treatments of neuropathic pain: The latest recommendations. Rev Neurol (Paris). 2019; 175(1-2): 46-50, doi: 10.1016/j.neurol.2018.08.005, indexed in Pubmed: 30318260.

40. Park SH, Wackernah RC, Stimmel GL. Serotonin syndrome: is it a reason to avoid the use of tramadol with antidepressants? J Pharm Pract. 2014; 27(1): 71-78, doi: 10.1177/0897190013504957, indexed in Pubmed: 24153222.

41. van Nooten F, Treur M, Pantiri K, et al. Capsaicin $8 \%$ Patch Versus Oral Neuropathic Pain Medications for the Treatment of Painful Diabetic Peripheral Neuropathy: A Systematic Literature Review and Network Meta-analysis. Clin Ther. 2017; 39(4): 787-803.e18, doi: 10.1016/j.clinthera.2017.02.010, indexed in Pubmed: 28365034.

42. Suchorzewski M, Wujtewicz M. Opioidy w leczeniu bólu neuropatycznego. Medycyna Paliatywna w Praktyce. 2007; 1(2): 49-53.

43. Bechakra M, Moerdijk F, van Rosmalen J, et al. Opioid responsiveness of nociceptive versus mixed pain in clinical cancer patients. Eur J Cancer. 2018; 105: 79-87, doi: 10.1016/j. ejca.2018.09.036, indexed in Pubmed: 30439627.

44. Davis AM, Inturrisi CE. d-Methadone blocks morphine tolerance and $\mathrm{N}$-methyl-D-aspartate-induced hyperalgesia. J Pharmacol Exp Ther. 1999; 289(2): 1048-1053, indexed in Pubmed: 10215686.

45. McNicol ED, Ferguson MC, Schumann R. Methadone for neuropathic pain in adults. Cochrane Database Syst Rev. 2017; 5: CD012499, doi: 10.1002/14651858.CD012499. pub2, indexed in Pubmed: 28514508.

46. Induru RR, Davis MP. Buprenorphine for neuropathic pain--targeting hyperalgesia. Am J Hosp Palliat Care. 2009; 26(6): 470-473, doi: 10.1177/1049909109341868, indexed in Pubmed: 19666890.

47. Butler $\mathrm{S}$. Buprenorphine-Clinically useful but often misunderstood. Scand J Pain. 2013; 4(3): 148-152, doi: 10.1016/j. sjpain.2013.05.004, indexed in Pubmed: 29913911.

48. Wiffen PJ, Derry S, Moore RA, et al. Buprenorphine for neuropathic pain in adults. Cochrane Database Syst Rev. 2015(9): CD011603, doi: 10.1002/14651858.CD011603. pub2, indexed in Pubmed: 26421677.

49. Duehmke RM, Derry S, Wiffen PJ, et al. Tramadol for neuropathic pain in adults. Cochrane Database Syst Rev. 2017; 6: CD003726, doi: 10.1002/14651858.CD003726. pub4, indexed in Pubmed: 28616956.

50. Galiè E, Villani V, Terrenato I, et al. Tapentadol in neuropathic pain cancer patients: a prospective open label study. Neurol Sci. 2017; 38(10): 1747-1752, doi: 10.1007/s10072017-3035-1, indexed in Pubmed: 28699105.

51. Yang Mi, Zhou M, He Li, et al. Non-antiepileptic drugs for trigeminal neuralgia. Cochrane Database Syst Rev. 2011(1): CD004029, doi: 10.1002/14651858.CD004029. pub3, indexed in Pubmed: 21249658.

52. Zhou M, Chen N, He Li, et al. Oxcarbazepine for neuropathic pain. Cochrane Database of Systematic Reviews. 2017, doi: 10.1002/14651858.cd007963.pub3.

53. Fallon MT, Wilcock $A$, Kelly $C A$, et al. Oral Ketamine vs Placebo in Patients With Cancer-Related Neuropathic Pain: A Randomized Clinical Trial. JAMA Oncol. 2018; 4(6): 870-872, doi: 10.1001/jamaoncol.2018.0131, indexed in Pubmed: 29621378. 


\section{Ból neuropatyczny — nowe mechanizmy działania starych leków}

Artykuł jest tłumaczeniem pracy: Żylicz Z., Neuropathic pain: new mechanisms of action of old drugs. Palliat. Med. Pract. 2019 tom 13, nr 3: 123-128.

Należy cytować wersję pierwotną.

Piśmiennictwo znajduje się na stronach 127-128

\section{Streszczenie}

Ból neuropatyczny występuje u około $7-10 \%$ ogólnej populacji i u około $30 \%$ chorych na nowotwory, spowodowany jest uszkodzeniem lub chorobą elementów układu nerwowego. Ból neuropatyczny może być skutkiem ucisku na nerw lub inną strukturę układu nerwowego. Najczęściej ból neuropatyczny wiąże się z sensytyzacją i zmianami w ośrodkowym układzie nerwowym, którego struktury stają się tak wrażliwe na sygnały bólowe z obwodu, że ich aktywacja jest trwała i niezależna od zmian pierwotnych. W ostatnich latach coraz częściej ból neuropatyczny wiązany jest z aktywacją mechanizmów immunologicznych i receptorów Toll-like należących do systemu wrodzonej odporności, które są hamowane przez wiele leków. Leczenie bólu neuropatycznego, o ile jest to możliwe, polega na odbarczeniu nerwu lub na farmakologicznym łagodzeniu pobudzenia ośrodków nerwowych. Najbardziej przydatne są gabapentynoidy, które hamują transport jonów wapnia przez błony komórkowe. Leki przeciwdepresyjne z grupy SNRI, takie jak duloksetyna czy wenlafaksyna, wykazują także udokumentowane działanie w bólu neuropatycznym podobnie jak trójcykliczne leki przeciwdepresyjne, te ostatnie cechują jednak znaczne działania niepożądane. W niektórych rodzajach bólu neuropatycznego korzystne efekty wykazuje $8 \%$ kapsaicyna i 5\% lidokaina w plastrach, toksyna botulinowa i niektóre opioidy, nadal jednak brakuje kontrolowanych badań klinicznych. Opisanie roli receptorów Toll-like w patomechanizmie bólu neuropatycznego stanowi przełom i daje nadzieję na opracowanie nowych, skuteczniejszych metod leczenia.

Palliat Med Pract 2019; 13, 3: 129-133

Słowa kluczowe: ból neuropatyczny, sensytyzacja OUN, receptory Toll-like, trójcykliczne leki przeciwdepresyjne, gabapentyna, pregabalina, opioidy

\section{Wstęp}

Ból przewlekły występuje często lub w sposób ciągły przez okres kilku miesięcy, w ogólnej populacji jedna na pięć osób cierpi z powodu przewlekłego bólu [1]. Ze względu na patomechanizm, ból przewlekły można podzielić na ból zapalny i ból neuropatyczny (NP, neuropathic pain), chociaż w praktyce klinicznej stwierdza się często ból o etiologii mieszanej. Ból neuropatycz- ny jest spowodowany uszkodzeniem albo chorobą somato-sensorycznego układu nerwowego [2]. $\mathrm{Na}$ podstawie systematycznego przeglądu badań, współczynnik chorobowości dla NP w populacji ogólnej określono na 6,9-10\% [3], co oznacza, że niemal połowa osób doświadczająca przewlekłego bólu, cierpi na NP. U chorych na nowotwory częstość występowania NP, na podstawie przeglądu 29 badań, wynosi 31,2\% [4], może być jednak wyższa, ponieważ w tej grupie

\footnotetext{
Adres do korespondencji:

Zbigniew Żylicz

Instytut Medycyny Doświadczalnej i Klinicznej, Uniwersytet Rzeszowski, Polska

ul. Kopisto 2a, Rzeszów

e-mail: z.zylicz@ur.edu.pl
} 
pacjentów często stwierdza się ból mieszany, zarówno zapalny, jak i neuropatyczny [5].

Ból neuropatyczny w czystej postaci jest trudny do leczenia, ponieważ jego przyczyny są złożone i niejednokrotnie bardzo różne. Obecnie nie jest i prawdopodobnie również w przyszłości nie będzie dostępny jeden skuteczny lek $w$ terapii wszystkich rodzajów $\mathrm{NP}$, jednak wiele leków jest stosowanych w różnych rodzajach NP. Do skutecznego leczenia NP niezbędna jest znajomość często złożonego patmechanizmu, a także różnicowanie objawów bólowych.

\section{Patomechanizm bólu neuropatycznego}

Określenie NP dotyczy wielu zespołów bólowych, których wspólną cechę stanowi uszkodzenie nerwu lub rdzenia kręgowego, rzadziej ośrodków mózgowych. To uszkodzenie może być odwracalne, jak w przypadku neuropatii uciskowych we wczesnej fazie, ale może być trwałe i nieodwracalne, jak na przykład po przecięciu nerwu podczas zabiegu chirurgicznego. Nerwy i rdzeń kręgowy mogą być uszkodzone substancjami toksycznymi (np. chemioterapia), promieniowaniem jonizującym (np. radioterapia), zapaleniem nerwu (np. infekcja wirusem varicella zoster). Dodatkowo, nerw może ulec uszkodzeniu poprzez zmiany metabolizmu (np. w cukrzycy) i wiele innych czynników, z których nie wszystkie zostały do tej pory poznane. Badania nad patomechanizmem NP są trudne, gdyż modele zwierzęce (np. zaciśnięcie nerwu kulszowego u szczurów) nie w pełni odzwierciedlają patologię u człowieka [6], a także prawdopodobnie zwierzęta nie doświadczają zaburzeń emocjonalnych na skutek zabiegu. Dostępne są również inne modele zwierzęce uszkodzenia nerwu, ale trudność polega na przełożeniu danych doświadczalnych na patomechanizm i odczuwanie NP przez człowieka.

Proces powstawania NP można podzielić na trzy fazy. Faza pierwsza to uszkodzenie, faza druga to próba regeneracji nerwu [6], faza trzecia to wtórne zmiany w OUN nazywane ogólnie sensytyzacją ośrodkową [7]. Po uszkodzeniu nerwu albo innej struktury nerwowej, dochodzi do rozwoju martwicy i zaniku zarówno części dystalnej, jak i proksymalnej uszkodzonych aksonów. W ośrodkach rdzenia kręgowego i mózgu dochodzi do odpowiedzi troficznej, między innymi zwiększenia ekspresji genów i syntezy czynników wzrostowych nerwów (neurotrofin), w tym czynnika wzrostu nerwów (NGF, nerve growth factor) [7]. Neurotrofiny i ich prekursory są odpowiedzialne za regenerację aksonów, które, jeżeli jest to możliwe, wrastają w istniejące osłonki nerwów. Jednocześnie neurotrofiny, między innymi NGF, aktywują makrofagi i komórki mikrogleju i stanowią element procesu za- palenia neurogennego [8], który jest odpowiedzialny za utrwalenie, czyli chronifikację bólu [9].

Najczęściej dochodzi do skutecznej regeneracji nerwu, a objawy hipoalgezji i drętwienia ustępują po kilku miesiącach, w zależności od długości aksonu. Regeneracja najdłuższych nerwów w stopie może być znacząco dłuższa, w porównaniu z nerwem skórnym na tułowiu przeciętego przez chirurga, na przykład podczas przeprowadzania operacji jamy brzusznej. Jeżeli dochodzi do całkowitej regeneracji nerwu, proces zapalenia neurogennego stopniowo ustępuje. W niektórych przypadkach proces regeneracji może być niecałkowity albo zaburzony, na przykład w cukrzycy [6], co sprzyja chronifikacji bólu i utrzymywaniu się zapalenia neurogennego. Co więcej, proces ten może się rozszerzać i być coraz bardziej intensywny. Jeżeli aksony nie są $w$ stanie wrosnąć $w$ istniejące osłonki nerwowe albo na swojej drodze napotykają przeszkody, takie jak blizna lub koniec nerwu jest amputowany, aksony rosną chaotycznie $\mathrm{w}$ postaci niewielkiego guzka - nerwiaka (neuroma), który jest bardzo wrażliwy na uraz mechaniczny i może być przyczyną nasilonego bólu [10, 11].

W ostatnich latach zwrócono uwagę na rolę receptorów Toll-like [12] znajdujących się na powierzchni komórek mikrogleju w rdzeniu kręgowym. U człowieka stwierdzono 10 różnych rodzajów tych receptorów i jedynie niektóre (najbardziej znane to TLR-2 i TLR-4) związane są z chronifikacją bólu, w tym NP [13-15]. Receptory te stanowią bardzo istotny element systemu odporności wrodzonej (innate immunity), przy czym $\mathrm{w}$ organizmie człowieka szybko reagują na zmiany w środowisku wewnętrznym i zewnętrznym. Po infekcji na przykład bakteriami tyfusu, do OUN wysyłane są sygnały z flory jelitowej poprzez lipopolisacharydy (LPS) pochodzenia bakteryjnego, które ulegają wiązaniu z receptorami i powodują kaskadę reakcji polegającą na produkcji cytokin zapalnych [16], które są odpowiedzialne za zneutralizowanie i usunięcie $z$ organizmu bakterii (zapalenie neurogenne). W niektórych warunkach, na przykład przy zaburzeniach mikrobiomu w jelicie grubym, dochodzi do ciągłej stymulacji receptorów Toll-like [17]. Tego rodzaju procesy odpowiedzialne są, po latach, za niemal wszystkie choroby neurodegeneracyjne [18-20], depresję psychiczną [21], rozwój tolerancji i hiperalgezji wywołanej opioidami [22].

Receptory Toll-like są interesujące również dlatego, że reagują z różnymi lekami. Metabolit morfiny, morfino-3-glukuronid, reaguje $z$ TLR-4 i powoduje wzmożenie produkcji cytokin prozapalnych, co z kolei wywołuje działanie pronocyceptywne (osłabienie analgezji) [23, 24]. Powyższe może wyjaśnić rozwój hiperalgezji indukowanej opioidami, w tym przypad- 
ku wywołanej podaniem morfiny. Receptory Toll-like reagują także z innymi opioidami, takimi jak fentanyl [25], co wyjaśnia krótkotrwały efekt leku w terapii NP [26] i zmniejszenie jego skuteczności z upływem czasu na skutek aktywacji zapalenia neurogennego i działania przeciwanalgetycznego [27]. Receptory Toll-like reagują także z naloksonem (zarówno lewo-, jak i prawoskrętnym), co prowadzi do zahamowania rozwoju zapalenia neurogennego [28]. Jest to istotne, ponieważ (+) nalokson, który jest nieaktywny, jako antagonista opioidowy, okazał się skuteczny w leczeniu NP u zwierząt [15]. Trójcykliczne leki przeciwdepresyjne hamują aktywację receptorów Toll-like [29], co może wyjaśniać ich działanie przeciwbólowe w NP.

Innym receptorem, który odgrywa istotną rolę w rozwoju sensytyzacji i hiperalgezji jest receptor glutaminowy NMDA (N-Methyl-D-Aspartate) [30]. Receptor ten, a właściwie kanał jonowy, reaguje na połączenie $z$ kwasem glutaminowym uwolnieniem jonu magnezu, który kanał blokuje. Niedobór magnezu powoduje „otwarcie”, czyli uaktywnienie kanału jonowego, podczas kiedy siarczan magnezu podany drogą parenteralną jest skutecznym, choć w mniejszym stopniu niż ketamina, inhibitorem receptora NMDA [31]. Efekty podania ketaminy są prawdopodobnie również związane $\mathrm{z}$ interakcją z receptorami Toll-like [32].

Zahamowanie sensytyzacji OUN powoduje hamowanie kanałów wapniowych po podaniu gabapentyny i pregabaliny (gabapentynoidy), które zmniejszają wrażliwość rogów tylnych rdzenia kręgowego poprzez kilka mechanizmów [33]. Leki z tej grupy hamują transport wapnia i blokują uwalnianie pronocyceptywnych neurotransmiterów poprzez zahamowanie podjednostki $\alpha 2 \delta$-1 i aktywują wychwyt glutaminianu przez białka transporterów aminokwasów pobudzających [34]. Inne mechanizmy działania gabapentynoidów obejmują wpływ na sferę emocji, istotną dla odczuwania bólu, dlatego pregabalina coraz częściej wykorzystywana jest w psychiatrii [35]. W medycynie paliatywnej gabapentynoidy stosowane są także w leczeniu objawów, takich jak: kaszel, zespół niespokojnych nóg, świąd i czkawka, których wystąpienie jest skutkiem sensytyzacji OUN [36].

\section{Rozpoznanie bólu neuropatycznego}

Kliniczne rozpoznanie NP ustala się na podstawie wywiadu i badania przedmiotowego. Chory cierpiący na NP może odczuwać spontanicznie bóle kłujące, przeszywające, "ból jak po impulsie elektrycznym”, drętwienie, strzelanie, rwanie i palenie. Pacjent może używać innych słów i opisu bólu niż podane powyżej. Liczne kwestionariusze mogą być pomocne w usta- leniu rozpoznania NP [37], jednak ich stosowanie jest pracochłonne i używane są częściej w badaniach naukowych niż w praktyce klinicznej, kiedy zwłaszcza w kontekście długotrwałego leczenia bólu, bardziej przydatne są skale oceny natężenia bólu [15].

W badaniu przedmiotowym najważniejszą rolę odgrywa badanie czucia powierzchownego na skórze, którego zaburzenia określane są jako dyzestezje. Czucie może być osłabione (hipoestezja) lub chory może być nadwrażliwy, nie tylko na impulsy naturalnie bolesne (hiperalgezja), ale także na dotknięcie wacikiem lub opuszką palca (allodynia). Badanie przeprowadza się specjalnymi, tępymi igłami lub rozgiętym spinaczem biurowym, a także wacikiem. Ważne jest ustalenie, czy obserwowane zmiany dotyczą obszaru zaopatrywanego przez jeden nerw czy korzeń nerwowy (dermatom). W pierwszym przypadku hiperalgezja (test tępymi igłami) w obszarze jednego nerwu będzie sugerowała zajęcie lub ucisk nerwu na obwodzie. Jeżeli obszar hiperalgezji będzie się pokrywał z dermatomem, sugerowane jest uszkodzenie na poziomie segmentu rdzenia kręgowego i korzenia nerwowego. W takim przypadku wskazane jest wykonanie badania obrazowego, na przykład MRI kręgosłupa. Ból spowodowany uciskiem na nerw można sprowokować uciskiem lub palpacją okolicy przebiegu nerwu, co niekiedy wywołuje promieniowanie bólu wzdłuż uciśniętego nerwu. Lekarz leczący powinien także dokonać dokładnego opisu zjawiska bólowego wraz z oceną natężenia bólu w skali Numeric Rating Scale (NRS) [15], odczuwanego zarówno spontanicznie, jak i po stymulacji, co odgrywa istotną rolę w późniejszej ocenie skuteczności leczenia.

\section{Leczenie bólu neuropatycznego}

Najprostsze jest leczenie neuropatii nieutrwalonych spowodowanych uciskiem na nerw. Bardzo ważne jest odbarczenie nerwu poprzez wykonanie zabiegu chirurgicznego. Leczenie farmakologiczne często obejmuje stosowanie kortykosteroidów (najczęściej podawany jest deksametazon drogą doustną lub parenteralną), które wykazują działanie przeciwzapalne i przeciwobrzękowe, przydatne także w terapii podwyższonego ciśnienia śródczaszkowego i ucisku na rdzeń kręgowy. W przypadku ucisku guza na strukturę nerwową (np. splot nerwowy) kortykosteroidy można stosować $w$ połączeniu $z$ radioterapią albo chemioterapią. W praktyce opieki paliatywnej często występuje nasilony ból spowodowany uciskiem pojedynczego nerwu o krawędź kostną, ścięgno lub uwięźnięcie nerwu w bardzo napiętym mięśniu - najlepiej zastosować wówczas miejscowe ostrzykiwanie nerwu mieszaniną metylprednizolonu i bupiwakiny [38]. 
Niestety, większość chorych odczuwających NP zgłasza się do lekarza późno z nieodwracalnymi zmianami, celem leczenia jest wówczas ograniczenie sensytyzacji OUN. Dotychczas sądzono, że w leczeniu NP skuteczne są leki wpływające na zwrotny wychwyt monoamin, a także blokujące kanały sodowe. Obecnie nie jest jasne, czy rzeczywiście wymienione mechanizmy są najważniejsze, gdyż okazało się, że trójcykliczne leki przeciwdepresyjne mogą oddziaływać przez receptory Toll-like, a leki przeciwdepresyjne hamujące zwrotny wychwyt serotoniny (SSRI) są nieskuteczne w leczeniu NP.

Skuteczność trójcyklicznych leków przeciwdepresyjnych (TCA) jest wystarczająco ustalona [39]. Mechanizm działania tej grupy leków nie został dokładnie poznany, powodują jednak wiele działań niepożądanych, które u pacjentów z zaawansowaną chorobą i u osób starszych mogą być bardzo uciążliwe. Za działania niepożądane odpowiedzialny jest głównie efekt cholinolityczny, który nie jest niezbędny dla uzyskania efektu przeciwbólowego. Liczba chorych wymagających leczenia, aby u jednego pacjenta uzyskać przynajmniej 50\% zmniejszenia natężenia bólu (NNT, number needed to treat) wynosi 3,6 (3,0-4,4) [39]. Amitryptylina jest najbardziej znanym lekiem, ale powoduje także wiele działań niepożądanych. Pod tym względem znacznie lepiej tolerowane są, niestety trudno dostępne w Polsce, imipramina i nortryptylina. trójcykliczne leki przeciwdepresyjne należy podawać zwykle raz dziennie przed snem, zaczynając od małych dawek, nie należy nagle przerywać leczenia. Jak już wspomniano, TCA hamują aktywność receptorów TolI-like i być może ten mechanizm jest odpowiedzialny za efekty przeciwbólowe w NP. Ponieważ receptory Toll-like nie są stereospecyficzne, prawoskrętne enancjomery leków mogą wykazywać efekt hamujący na receptory Toll-like, jednocześnie posiadają inny profil działań niepożądanych [28]. Obecnie brak wiedzy, jaką rolę odgrywa mechanizm hamowania zapalenia neurogennego w skuteczności tej grupy leków.

Nowsze leki przeciwdepresyjne, o podobnym jak TCA mechanizmie działania, to duloksetyna i wenlafaksyna (SNRI). Leki te powodują znacznie mniej działań niepożądanych, w porównaniu z TCA. Dla tej grupy leków NNT wynosi 6,4 (5,2-8,4). Działania niepożądane obejmują nudności, wymioty i zaparcia stolca, a także wzrost ciśnienia tętniczego krwi. Leki należy podawać w mniejszych dawkach u chorych z niewydolnością wątroby i niewydolnością serca, a także nie łączyć z tramadolem, z powodu ryzyka wywołania zespołu serotoninowego [40].

Obecnie najczęściej stosowane są gabapentynoidy: gabapentyna i pregabalina, które hamują kanały wapniowe i przyczyniają się do zmniejszenia sensytyzacji
OUN. Leki te są zwykle dobrze tolerowane, a działania niepożądane zwykle o niewielkim nasileniu. Chociaż NNT dla gabapentyny wynosi $6,3(5,0-8,4)$, a dla pregabaliny $7,7(6,5-9,4)$ [39], leki zalicza się do najbardziej skutecznych w leczeniu NP.

Plastry zawierające 5-procentową lidokainę, która hamuje kanały sodowe, stosowane są miejscowo, jeżeli ból jest ograniczony do niewielkiej powierzchni skóry. Do tej pory nie ustalono NNT [39], ale działania niepożądane są bardzo niewielkie, lek nie jest przeciwskazany u pacjentów z chorobami serca. Niestety, leki antyarytmiczne podawane drogą doustną okazały się mało skuteczne i obciążone poważnymi działaniami niepożądanymi. Innym leczeniem miejscowym jest 8-procentowa kapsaicyna stosowana w plastrach, która hamuje receptory waniloidowe typu 1 (TRPV1) w skórze. NNT wynosi 10,6 (7,4-19) [39], jednak do tej pory przeprowadzono zbyt mało kontrolowanych badań klinicznych, aby jednoznacznie ustalić skuteczność leczenia [39]. Lek jest bardzo drogi i dość trudny w stosowaniu. Bezpieczne leczenie jest możliwe w specjalistycznych poradniach leczenia bólu, w których pracują przeszkoleni w tym zakresie lekarze i pielęgniarki. Kapsaicyna podana w tym stężeniu, przy kontakcie z rogówką oka, może spowodować ślepotę [41].

Innym miejscowo działającym lekiem, o wysokiej skuteczności, NNT 1,9 (1,5-2,4) [39] jest toksyna botulinowa typu A. Po wstrzyknięciu w okolicę bolesną hamuje wyrzut acetylocholiny i zmniejsza aktywność mięśni poprzecznie prążkowanych. Lek jest bardzo przydatny w leczeniu uwięźnięcia nerwu w bardzo napiętym mięśniu, na przykład w neuropatii uciskowej nerwu potylicznego większego, powodującej silne, napadowe bóle głowy [38].

Stosowanie opioidów w leczeniu NP jest dość kontrowersyjne, zwłaszcza w bólu pochodzenia nienowotworowego [42]. Z jednej strony NNT dla opioidów jest dość niskie 4,3 $(3,4-5,8)$ [39], jednak podczas leczenia obserwuje się więcej działań niepożądanych i stosunkowo szybki rozwój tolerancji, w porównaniu z leczeniem innych rodzajów bólu [42]. Najlepsze wyniki uzyskiwane są w leczeniu bólu o charakterze mieszanym zapalnym i neuropatycznym [43]. $Z$ drugiej strony, tradycyjnie uważa się, że niektóre opioidy posiadają specyficzne własności korzystne w leczeniu NP. Przykładowo metadon posiada dodatkowe działanie przeciwbólowe poprzez zahamowanie receptora NMDA przez prawoskrętny izomer D-metadonu [44], jednak w kontrolowanych badaniach klinicznych większa skuteczność metadonu w leczeniu NP nie została potwierdzona [45].

Innym opioidem o "specjalnych" własnościach w leczeniu NP jest buprenorfina, najczęściej stosowana 
w plastrach [46], która wykazuje działania podobne do leków miejscowo znieczulających, czyli blokowanie kanałów sodowych [47], jednak brakuje dowodów klinicznych na takie działanie leku. W dziesięciu kontrolowanych badaniach nie wykazano skuteczniejszego efektu analgetycznego buprenorfiny w NP [48]. Buprenorfinę najczęściej stosuje się w połączeniu z gabapentyną lub pregabaliną, można ją podawać u chorych z niewydolnością nerek. Opioidem o "specjalnych" własnościach w NP jest tramadol [49], „słaby” opioid o złożonym mechanizmie działania przeciwbólowego. Dla tramadolu NNT wynosi 4,7 (3,6-6,7) [39], podczas kiedy dla innych "silnych" opioidów jest on niższy, jednak liczba dowodów na skuteczność tramadolu w leczeniu NP jest ograniczona [49].

Tradycyjnie, w leczeniu NP stosowane są inne leki, które w świetle uzyskanych dowodów klinicznych, uzyskały jedynie ograniczone rekomendacje [39]. Niestety, tapentadol do tej pory nie okazał się przełomem; pomimo obiecujących wyników niektórych badań [50], dostępnych jest zbyt mało niezależnych danych klinicznych potwierdzających skuteczność tapentadolu w leczeniu NP. Inne niż gabapentynoidy leki przeciwdrgawkowe nie znajdują szerszego zastosowania w leczeniu bólu neuropatycznego. Karbamazepina stosowana jest jedynie w leczeniu neuralgii nerwu trójdzielnego $z$ powodu licznych działań niepożądanych i interakcji z innymi lekami [51]. Pochodna karbamazepiny - okskarbazepina jest lekiem mniej toksycznym, ale dowody na jej skuteczność są także ograniczone [52]. Ketamina, inhibitor receptorów
NMDA, tradycyjnie od wielu lat stosowana w leczeniu bólu u chorych na nowotwory, w tym NP, w badaniach kontrolowanych porównujących lek podawany drogą doustną z placebo, okazała się nieskuteczna [53].

\section{Podsumowanie}

Utrwalony NP jest trudny do leczenia, a jego patomechanizm jest bardzo różnorodny i nadal słabo poznany. W wielu przypadkach silnego NP wskazane jest łączenie różnych leków. Typowym dla leczenia NP jest metoda „prób i błędów", kiedy u jednego pacjenta leki zmieniane są wielokrotnie, co negatywnie wpływa na psychikę chorego, a także na zaufanie do lekarzy leczących. Wielu chorych samodzielnie używa innych leków, które potencjalnie mogą okazać się szkodliwe.

Na podstawie coraz lepszej znajomości patomechanizmu NP można oczekiwać w najbliższej przyszłości nowych, bardziej skutecznych leków. Coraz większe znaczenie receptorów Toll-like $w$ patomechanizmie NP posiada jeszcze inne aspekty. Leki, które okazały się skuteczne w leczeniu NP, takie jak amitryptylina, być może działają w zupełnie inny sposób niż dotychczas sądzono. Ponieważ receptory Toll-like nie są stereo-wybiórcze, a większość leków podawanych chorym to mieszaniny enancjomerów (racematy), warto rozważyć, czy enancjomery, które zawsze uważano za nieaktywne, nie są odpowiedzialne za działanie farmakologiczne [14, 15], przynajmniej u zwierząt doświadczalnych, co otwiera zupełnie nowe możliwości badań nad nowymi lekami. 